\title{
2002: A JUSTICE ODYSSEY
}

\author{
Kim Economides*
}

Professor Economides, 2002 Chapman Tripp visiting fellow, overviews research on the supply side of the access to justice equation. Economides argues that the justice equation is based on the nature of supply and demand for legal services and the nature of the claim that clients wish to bring to a legal forum. However, the access to justice theme is moved beyond the supply side and into questions regarding the quality of the access provided suggesting that there is a need to explore the understandings of justice held by members of the legal profession and legal ethics, and the role that law schools and legal education have in formulating these.

\section{ORIENTATION}

Karanga mai, mihi mai,

Tena koutou, tena koutou katoa. ${ }^{1}$

As a non-Maori I am conscious that I may inadvertently cause offence through not fully comprehending the different Marae kawa ${ }^{2}$ shared by different tribes comprising Maoridom, which to some extent may act as a substitute for formal law. ${ }^{3}$ It might be said that as an outsider observing

* 2002 Chapman Tripp Visiting Fellow, Faculty of Law, Victoria University of Wellington; Professor of Legal Ethics and Head of the School of Law, University of Exeter, United Kingdom. The article is based on a public lecture delivered to the New Zealand Centre for Public Law in Wellington on 19 April 2002.

1 A Maori greeting that translates, "Thank you for your welcome. Greetings, greetings to you all". I wish to acknowledge the generous support of the leading law firm Chapman Tripp that enabled me to visit New Zealand and to thank Dean Palmer, his colleagues and students at the Faculty of Law, Victoria University of Wellington for providing such a convivial and stimulating working environment. I have also benefited greatly from discussions with participants at two seminars I gave in the Faculty of Law at Victoria University, Alison Stephens and members of the Access to Justice Team at the Ministry of Justice, Tim Bannatyne and Frances Blythe of the Legal Services Agency, Margaret Thompson of the Law Commission and Duncan Webb, of the School of Law at the University of Canterbury, none of whom is of course responsible for any opinions or mistakes that must remain my sole responsibility.

2 Translates to customs and procedures.

3 See Hiwi Tauroa and Patricia Tauroa Te Marae: A Guide to Customs \& Protocol (Reed Methuen, Auckland, 1986). John Patterson Exploring Maori Values (Dunmore Press, Palmerston North, 1992) 102 notes that: "... there is in classical Maori no word for 'law' ... This does not mean that there was no law - 
various elements of New Zealand's legal system I am: He kuku ki te kainga, he haka ki te haere. ${ }^{4}$ My purpose this evening is neither to wade into internal debates concerning current law reform, nor to criticise well-established local customs and practices I am unfamiliar with. ${ }^{5}$ Rather I wish to create a context within which we may better understand some of the challenges confronting modern legal systems struggling to become more accessible to that (often silent) group legal professions invariably claim to represent: namely citizens. My title alludes to Kubrick's masterwork 2001: A Space Odyssey ${ }^{6}$ - which begins a voyage into the future in the past - and is intended to bring together what are essentially personal reflections arising out of an intellectual odyssey which began twenty-six years ago when, as a young researcher working with the leading Italian comparative lawyer Professor Mauro Cappelletti on his famous Florence Access to Justice Project, I was first attracted to and inspired by the international "Access to Justice Movement". ${ }^{7}$

Around two decades ago after trying to persuade policy-makers of the need for a rural law centre (or Community Legal Centre) in Devon, which finally was launched last October, I developed and co-directed another interdisciplinary project with geographers examining access to justice in rural communities - particularly in Southwest England - called the Access to Justice in Rural Britain Project (AJRBP). ${ }^{8}$ This study involved an empirical investigation of the distribution and work of lawyers - including paralegals - and also research into the legal needs (or contacts) of the inhabitants of three remote rural parishes. Three control studies in other parts of the United

only that there was no need to formulate it into an explicit code of rules. Instead, the way of Maori law is to follow the ancestors, who are the model to the kinship group".

4 A Maori saying which supposedly refers to "A person who is as quiet as a pigeon in his own village chatters like a parrot when away from home and finds fault with everything", Aileen E Brougham Maori Proverbs (Reed, Auckland, 1992).

5 For a general introduction to the legal system in New Zealand see Morag McDowell and Duncan Webb The New Zealand Legal System: Structures, Processes \& Legal Theory (3 ed, Butterworths, Wellington, 2002).

6 Stanley Kubrick and Arthur C Clarke 2001: A Space Odyssey (Turner Entertainment, Atlanta, 1968). For the book, see Arthur C Clarke 2001: A Space Odyssey (Hutchinson, London, 1968).

7 Homer's Odysseus took 26 years to complete his epic voyage and, like Stanley Kubrick, I am interested in the relationship between man and technology, in particular drawing attention to the human element in the justice system. This humanistic perspective on civil justice has its roots in the Florence Access to Justice Project: Mauro Cappelletti and Bryant Garth (eds) Access to Justice (Milan, Giuffrè, 1978-1979); (Alphen aan den Rijn, Sijthoff and Noordhoff, 1978-1979).

8 Access to Justice in Rural Britain Project (AJRBP) ESRC-funded project (1984-1987) E00232054. See Mark Blacksell, Kim Economides and Charles Watkins Justice Outside the City (Longman, Harlow, 1991); reviewed by Jon T Johnsen "Rural Justice: Country Lawyers and Legal Services in the United States and Britain" (1992) 17 Law and Social Inquiry 415. This project developed out of an attempt to set up a rural law centre based in Exeter, see further Kim Economides "Legal Services and Rural Deprivation" (1982) 15 Bracton Law Journal 41-78. Sir Stephen Sedley in Plymouth formally launched the Devon Law Centre on 22 October 2001. See also Kim Economides and Mark Blacksell "Access to Justice in Rural Britain: Final Report" (1987) 16 Anglo-Am LR 353. 
Kingdom were commissioned: in Scotland, Wales and in East Anglia to check the findings coming through in our surveys in Southwest England. This project established the importance of looking at both the supply and demand sides of legal service provision while also highlighting the complex relationship between the two.

My more recent work, which I consider also relevant to the broad theme of "access to justice", turns the inquiry inwards, as it were, away from legal service provision toward the whole field of legal ethics. And I would wish to argue today that the essence of the problem is no longer limited to citizens' access to justice, but rather, must also include that of lawyers' access to justice. Indeed, I would go so far as to argue that the former is quite useless without the latter.

The following observations, based on the above experience, will therefore concentrate more on the theme of accessing justice than interpreting citizenship. Instead of engaging in a discussion of the fundamental guarantees of modern constitutionalism (although I must concede there are important connections to be made between the theme of access to justice, constitutionalism and citizenship, as seen, for example, in the "right of action"9) I prefer to pitch my observations at an intermediate theoretical level which examine some practical determinants, as opposed to abstract definitions, of citizenship. My present aim is to explore some of the pragmatic consequences and policy lessons generated by research investigating the extent to which citizens actually enjoy access to the legal system - and I trust this falls within the remit of the New Zealand Centre for Public Law (NZCPL) and will be of interest to public lawyers.

Toward this end there are two broad areas I wish to consider. The first concerns the nature of the problem of access, including the methodological problems, surrounding previous studies on the mobilisation of law by citizens. I would like, moreover, also to consider policy questions directed at reforming law and legal services that aim to enhance their accessibility. The second area concerns contemporary definitions of justice, which seem to focus on managerial conceptions of "quality". In other words, the epistemological problem of how we can understand what it is that we actually wish to give citizens access to. Access to what? My principal argument is that we need to affect a shift from civil to civic justice. ${ }^{10}$ It is worth noting that Marshall's distinction between social and political rights is, in practice, often blurred since both categories are mediated and enforced through the modern welfare state and conflicts over entitlements invariably expressed through the medium of law. ${ }^{11}$ The assertion of such rights is something that is very much closely related to the work of

9 Mauro Cappelletti and William Cohen Comparative Constitutional Law (Bobbs-Merrill, Charlottesville, 1979) ch 6.

10 Louise Trubek and David Trubek "Civic Justice through Civil Justice: A New Approach to Public Interest Advocacy in the United States" in Mauro Cappelletti (ed) Access to Justice and the Welfare State (Alphen aan den rijn, Sijthoff, 1981) 119

11 Thomas H Marshall Citizenship and Social Class and Other Essays (Cambridge University Press, Cambridge, 1950). 
lawyers, even if they may choose not to recognise this fact. It may therefore be necessary to move away from a rigid application of Marshall's classifications, which, although helpful in terms of comprehending the scope of the problem, perhaps divert us away from important connections, which do or could exist at the level of practice. How might, or should, lawyers move beyond representing individualistic civil claims to actually articulate more collective, political, civic - or even perhaps social and economic - rights through the legal process?

The conclusion I shall reach, however, is that we must not be confined to this macro-political level, considering only the application and meaning of either distributive or corrective justice, terms typically defined in the Aristotelian sense. I shall be suggesting that now is the time to examine further, at the micro-level, the particular understandings of justice possessed by individual members of the legal profession. And I shall argue today that the contemporary access to justice movement must engage with the relatively new theme (at least for academic lawyers) of professional ethics. My tentative conclusion is not that we have to make a choice between these approaches, but rather that we must manage somehow to create, sustain and balance within our analysis of access to justice a novel synthesis between these macro- and micro- levels. We must steer between the Scylla of "access" and Charybdis of "quality" if we are to discover new ways of reaching justice.

\section{THE SCYLLA OF "ACCESS"}

After more than two decades of intense socio-legal and comparative research we understand the broad contours of the nature of the problem of access to justice, even if it must be conceded that effective practical solutions to the problem everywhere remain elusive. ${ }^{12}$ Policy-makers across different governments and jurisdictions - including New Zealand - seem permanently engaged in local experiments directed at finding the most promising solutions and continually introduce reform after reform in the hope of cutting the costs of justice without simultaneously undermining its accessibility. The evolution of access reforms is therefore very much a cross-cultural phenomenon which is also intimately bound up with transformations in global economies and nation-states, particularly the crisis in the modern welfare state and also, interestingly, with changing professional boundaries. My aim here is simply to summarise briefly some of the more important insights generated by research coming from Europe and North America. It goes without saying that these lessons that have arisen in specific social, political and economic contexts must be treated with caution. The socio-economic and demographic conditions that prevail in New Zealand mean that we should be hesitant about importing or mechanically transplanting reforms developed elsewhere. On the other hand, one should not exclude the possibility that home-grown experiences and

12 See Marc Galanter "Why the 'Haves' Come out Ahead: Speculation on the Limits of Legal Change" (1974) 9 Law and Society Review 95. See also Roger Smith and Sally M Lloyd-Bostock Why People go to Law: An Annotated Bibliography of Social Science Research (Centre for Socio-legal Studies, Oxford, 1990); Windsor Yearbook of Access to Justice (Faculty of Law, University of Windsor, Windsor (Ontario), 1981); Hazel Genn Paths to Justice: What People Do and Think About Going to Law (Hart, Oxford, 1999). 
perspectives could be exported in order to contribute to the quest for justice elsewhere and it is worth noting that New Zealand has in several significant areas acted as a legal laboratory contributing to reforms or debates carried out elsewhere in the common law world.

The creation of the new Legal Services Agency (LSA) set up under the new Legal Services Act 2000 replaces the previous Legal Services Board and closely resembles the shift in transfer of responsibilities in the United Kingdom when, following the Access to Justice Act 1999, the Legal Aid Board was superseded by a new Legal Services Commission (LSC). ${ }^{13}$ Both bodies are seeking to better understand and meet "legal needs" in order to make the legal system more accessible to various constituencies. But here in New Zealand more attention appears to be given to women, rural communities and the legal education of the population at large through "Law Related Education"(LRE). ${ }^{14}$

The key to an understanding of the nature of access to legal services is to perceive the problem in three-dimensional terms. The three elements we must keep in mind, if possible simultaneously, are these: (1) the nature of the demand for legal services; (2) the nature of the supply of legal services; and (3) the nature of the legal problem clients may wish to bring to a legal forum. And we should not forget that in practice a very close inter-relationship exists between all three variables. ${ }^{15}$

The early "unmet legal needs" studies, as they have become known, sought to objectively quantify need. There were also various studies done of attitudes of the general public in several jurisdictions - studies of the "knowledge and opinion of law" or "KOL studies" - perhaps the best known of which was directed by Adam Podgorecki, a Polish legal sociologist who investigated

13 See Legal Services Agency 2000-2001 Annual Report and Business Plan 2001-2004: Looking Forward (Legal Services Agency, Wellington, 2002) (LSA).

14 See Tim Bannatyne "The Future of Law Related Education in New Zealand" (Legal Services Research Conference, Oxford, 20 March 2002). See also report prepared by the LSA by NFO CM Research Review of Unmet Legal Needs in the Auckland Area: Quantitative and Qualitative Research Report (LSA, Wellington, 2001) and the project being developed by the LSA to assist rural communities in the West Coast of the South Island: paper by Janine McIntosh West Coast Qualitative Project Report (LSA, Wellington, 2002). The Law Commission has also conducted a major study into women's access to justice: New Zealand Law Commission Women's Access to Legal Services (NZLKC SP1, Wellington, 1999). See also research commissioned by the previous Legal Services Board: Gaye Maxwell, Paula Shepherd, Catherine Smith and Allison Morris Meeting Legal Service Needs (LSA, Wellington, 1999).

15 F Raymond Marks "Some Research Perspectives for Looking at Legal Need and Legal Services Delivery Systems: Old Forms or New?" (1977) 11 Law and Society Review 191; Lewis "Unmet Legal Needs" in Pauline Morris, Social Needs and Legal Action (Martin Robertson, London, 1973); Barbara Curran The Legal Needs of the Public: The Final Report of a National Survey, a Joint Undertaking by the American Bar Association Special Committee to Survey Legal Needs and the American Bar Association (The Foundation, Chicago, 1977); Michael Cass and Ronald Sackville Legal Needs of the Poor: Research Report (Australian Government Publishing Service, Canberra, 1975); Schuyt De Wag Naar Net Recht "The Road to Law" (Kluwer, Deventer, 1976; English Version (1977) European Yearbook in Law and Sociology 111). 
public attitudes to law. ${ }^{16}$ With hindsight, some of these studies now seem somewhat limited in scope. They fail to consider all of the complex processes determining entry to the legal system and the fact that access may often be a consequence of choice, rather than being determined by ignorance or the lack of economic resources. Furthermore, the assumption that the majority of the population either wants or needs to have access to the legal system today seems questionable in the light of the debate over "avoidance" of disputes. ${ }^{17}$ Some of these studies also reveal a rather crude understanding of the characteristics of clients and the legal services they were supposedly seeking to use. And finally, perhaps too heavy an emphasis was placed upon a crude economic explanation for the use, or non-use, of legal services, that is poverty.

In the 1960s, an important study in the United States, by Carlin and Howard, found that the poor did have access to justice in many instances, especially when they were in receipt of legal aid, and consequently this challenged the dominant economic explanation for lack of access. ${ }^{18}$ It was also becoming apparent that both the rich and organisations very often preferred not to use legal services and instead settled their disputes by more private or informal means. ${ }^{19}$ Although this was not a particularly new trend its discovery was novel as seen, for example, in work on law in nineteenth century England examining the significance of the early development of commercial arbitration. ${ }^{20}$ To return to the Carlin and Howard study, this was of seminal importance for it identified four crucial stages through which citizens must pass before they actually could enter court: ${ }^{21}$

Lack of economic resources represents only one element in a complex social process leading an individual to seek out and obtain legal representation. At least four steps are involved: (1) awareness or recognition of a problem as a legal problem; (2) willingness to take legal action for solution of the problem; (3) getting to a lawyer; and (4) actually hiring a lawyer.

The point to note about all of these early studies is that they focused almost exclusively on the characteristics of clients, or potential clients, wishing to avail themselves of legal services.

16 Adam Podgorecki Knowledge and Opinion about Law (Martin Robertson, London, 1973). See also, Maureen Cain and Kalman Kulcsar (eds) Disputes and the Law (Akadémiai Kiadó, Budapest, 1983).

17 William Felstiner "Influences of Social Organisation on Dispute Processing" (1974) 9 Law and Society Review 63; see also debate between Felstiner and Danzig and Lowy in Richard Danzig and Michael Lowy "Everyday Disputes and Mediation in the United States: A Reply to Professor Felstiner" (1975) 9 Law and Society Review 675, 695 and Robert Kidder "The End of the Road? Problems in the Analysis of Disputes" (1980-81) 15 Law and Society Review 717.

18 Jerome Carlin and Jan Howard "Legal Representation and Class Justice" (1965) 12 UCLA L Rev 381.

19 Stewart Macaulay "Non-Contractual Relations in Business: A Preliminary Study" (1963) 28 Am Soc Rev 55; Stewart Macaulay "Lawyers and Consumer Protection Laws" (1979) 14 Law and Society Review 115.

20 Robert B Ferguson "The Adjudication of Commercial Disputes" (1980) 7 British Journal of Law and Society 141 .

21 Carlin and Howard, above, 423. 
Gradually, however, a greater measure of methodological sophistication enters as researchers began to understand and appreciate the significance of psychological (and other) barriers to access to justice, particularly concerning the fear that people have of lawyers and of the legal system. In other words academic thinking about access started to transcend economic perspectives and new methodologies arose which focused attention on other barriers to justice. One might also mention the work in the United Kingdom, conducted in conjunction with geographers, which exposed the barrier of physical distance on access to legal services. ${ }^{22}$ Access to justice does have a significant geographical dimension but most of the earlier "legal needs" studies completely overlooked it.

In one of the most respected and widely cited studies of the United States Law and Society movement, Marc Galanter developed a more rigorous and comprehensive analytical framework, which drew attention to an important distinction between what he called "Repeat Players" (RPs) and "One-Shotters" (OSs). ${ }^{23}$ RPs referred to organisations or business plaintiffs with regular experience of the legal system who were able to deploy it strategically, and he contrasted this category of client with OSs which invariably were individual consumers having very limited, if any, regular experience of law and legal services. The OSs clearly lacked "legal competence", something more than mere control over economic resources, which implies the ability to apply strategic understanding, or tactical know-how, in order to manage the legal system in such a way as to secure long-term advantages. ${ }^{24}$

Although many of these early studies explained the use and non-use of legal services (and access to the legal system more generally) largely with reference to the attitudes, resources, and approach of individual clients, there developed in the 1970s an important alternative focus, which

22 Access to Justice in Rural Britain Project (AJRBP) ESRC-funded project (1984-1987) E00232054. See Mark Blacksell, Kim Economides and Charles Watkins Justice Outside the City (Longman, Harlow, 1991); reviewed by Jon T Johnsen "Rural Justice: Country Lawyers and Legal Services in the United States and Britain" (1992) 17 Law and Social Inquiry 415. This project developed out of an attempt to set up a rural law centre based in Exeter, see further Kim Economides "Legal Services and Rural Deprivation" (1982) 15 Bracton Law Journal 41. Sir Stephen Sedley in Plymouth formally launched the Devon Law Centre on 22 October 2001. See also Kim Economides and Mark Blacksell "Access to Justice in Rural Britain: Final Report" (1987) 16 Anglo-Am LR 353. This is obviously a particularly acute problem in any remote rural area and one that must affect many parts of New Zealand, which also contains indigenous populations in remote and relatively unexplored terrain. See further Kim Economides "Law and Geography: New Frontiers" in Philip Thomas (ed) Legal Frontiers (Dartmouth, Aldershot, 1996).

23 Mark Galanter "Why the 'Haves' Come out Ahead: Speculation on the Limits of Legal Change" (1974) 9 Law and Society Review 95.

24 See also Blacksell, Economides and Watkins, above, ch 6, which added a further dimension. This research showed that "legal competence" was not simply an individual characteristic determining client access. Also important is the immediate family and social network surrounding an individual - the wider competencies and legal experiences of friends and family are essential elements determining an individual's capacity to mobilise law and the legal system. 
came to be known as the "Social Organisation Theory". 25 The research by Mayhew and Reiss in the United States, who conducted a major study of the population in Michigan, focused attention not so much on clients but rather on the supply side of the lawyer-client equation: that is, the nature of legal services that were on offer. Broadly speaking, the lesson that emerges is that if one wishes to comprehend how it is that citizens access legal services one really does need to understand something about the nature of the work of lawyers, their attitudes and the style of legal services they provide. In other words, lawyers habitually serve particular categories of clients: large city firms invariably cater for corporate clients while the poor regularly receive legal aid from public defenders, criminal legal aid practitioners or family law practitioners. In all of these traditional categories of dispute clients can and do have access but, as the Dutch legal sociologist Schuyt explains, this still leaves significant gaps in provision: ${ }^{26}$

Lawyers serve individuals mostly in divorce cases; they do not to any great extent serve individuals in their conflicts with governments or organisations. On the contrary, lawyers serve corporate bodies and large organisations.

The point to note, however, is that the nature and style of legal service provision are both crucial factors influencing, if not determining, the mobilisation of law. ${ }^{27}$

The supply of legal services is something which is not only controlled by the private legal profession and it is worth pointing out that there are also important opportunities for local and central government to extend the scope of legal services in order to fill gaps left by the private market. So, for example, if government actively supports proactive legal services, not only through funding the work of the private legal profession via legal aid schemes, but also by investing directly in the work of courts, extra-judicial and para-legal services - citizens' access inevitably will be enhanced as a result. If, therefore, public legal services in the form of advice or justice centres are located in local communities close to where needs are particularly acute such proactive services could have a disproportionate effect in terms of stimulating the demand for, and use of, legal services. However, we should not ignore the fact that there are also powerful disincentives for any government contemplating such an investment: first, it may be defending the very legal actions it is funding; second, that stimulating litigation through the provision of informal procedures and small

25 Leon Mayhew and Albert Reiss, Jr "The Social Organisation of Legal Contacts" (1969) 34 Am Soc Rev 309; Leon Mayhew "Institutions of Legal Representation: Civil Justice and the Public" (1975) 9 Law and Society Review 401.

26 Kees Schuyt, Kees Groenendijk and Ben Sloot De weg naar het recht (Kluwer, Deventer, 1976). For the English version see Kees Schuyt, Kees Groenendijk and Ben Sloot "The Road to Law" in B M Blegvad, C M Campbell and C J Schuyt (eds) European Yearbook in Law and Sociology 1977 (Martinus Nijhoff, Dordrecht, 1977) 111.

27 Erhard Blankenburg "Mobilisation and the Law" (1984) 2 Government and Policy 461. 
claims courts could exacerbate overall problems of court congestion (and costs ${ }^{28}$ ) in the wider legal system; and third, direct investment in attacking the underlying causes of poverty and injustice might be a cheaper and more effective strategy to secure "justice" than reliance on lawyers and legal remedies. My argument here is simply that proactive legal services can act as a magnet attracting legal problems while, conversely, traditional legal services based on the market - where lawyers shelter themselves in downtown areas, behind offices and formal suits distant from local communities - merely reinforces the inequalities of the market by repelling unprofitable legal work. Legal aid is riddled with paradox and contradiction. ${ }^{29}$

Finally, the third dimension to the problem of legal service delivery is now better understood: that is that the type of legal problem is also an important variable determining access. As Schuyt points out above, there are clearly a whole range of disputes which no matter whether clients are rich or poor, they are ill served by any branch of the legal profession. This may in part be because the trial process artificially individualises conflicts, which in reality concern groups or the wider public interest. The legal process still does not appear to be well suited to representing large-scale claims, which have significant political or economic consequences for society at large. ${ }^{30}$ For example, environmental rights - or "meta-individual rights" - which transcend the interests of any particular individual yet affect all citizens often are not well-represented by either the suppliers of legal services or by particular groups of clients purporting to represent the wider class. I wish to conclude this part of my analysis by drawing attention to the interaction between the above three variables and making two broad observations. First, that the problem of access is not simply a problem of individual or citizen choice: responsibilities also fall on both government and the professional bodies in order to ensure that access is delivered to excluded groups. Second, that reliance on the market in many ways perpetuates gaps in legal service provision, seen not only in terms of areas of legal work but also in terms of geographical areas. If these gaps are ever to be filled this will require determined action by government - and also the legal professions - both acting in concert.

28 There has been an interesting debate in New Zealand on costs that illustrates this tension. Following a report of the Department for Courts (see: <http://www.courts.govt.nz/publications/papers.html >) fees for filing claims apparently have increased considerably despite the introduction of the Court Fees Waiver Act 2002 that was introduced to allow courts to waive fees upon application. See further the Minister for Courts press release: Matt Robson "Regulatory Impact and Compliance Cost Statement" (31 May 2001). Press release available at $<$ http://www.schnauer.co.nz/political/courtcosts.htm $>$ where the approach seems to be to shift "small claims" down to the informal Disputes Tribunal.

29 Richard Abel "The Paradoxes of Legal Aid" in Jeremy Cooper and Rajeev Dhavan (eds) Public Interest Law (Blackwell, Oxford, 1987).

30 Abram Chayes "The Role of the Judge in Public Law Litigation" (1976) 89 Harv L Rev 1281. 


\section{THE CHARYBDIS OF "QUALITY"}

I wish now to move on to consider more closely the nature, role and responsibilities of key policymakers inside government and the legal professions in providing the framework within which access reforms can develop to ask what is behind the so-called "quality" agenda. Some preliminary questions might usefully be put at this point: whose "access to justice" are we talking about? Why should government, or the professions, be at all bothered about our theme of "access to justice"? What consequences flow from the denial of access? One immediate response lies in the legitimation needs of both government and the legal professions whose credibility, if not survival, depends in part on the rhetoric surrounding rights and professional ideals being realised, at least to some extent, in practice. Access to justice thus connects with the twin themes of citizenship and constitutionalism by supporting and reinforcing the Rule of Law, which as the philosopher Roberto Mangabeira Unger notes, "has been truly said to be the soul of the modern state. The study of the legal system takes us straight to the central problems faced by the society itself". ${ }^{31}$ In other words, both political and professional legitimacy is at stake should it happen that there is a persistent and widespread denial of access to state-funded, or private professional, legal services.

In many Western European countries - and in particular Britain - the principal driving force behind current "access" reforms is neither an altruistic desire to enhance citizenship nor are these reforms a reaction to any crisis of confidence in professional or political ideals (though elements of both are clearly present); rather the overriding imperative of government policy appears to be finding new ways of reducing the costs of delivering legal services, which in most countries has been escalating beyond all control. ${ }^{32}$ In England and Wales, for example, the legal aid bill - I refer to the bill for not of rights - has been expanding exponentially and, although now slowing down, continues to direct massive amounts of public money toward the private profession despite signs that some discipline is now being exercised over spiralling costs. ${ }^{33}$ The current trends toward alternative legal services, informal justice, alternative dispute resolution (ADR) and conditional fee arrangements should all be seen as attempts to divert, reduce or spread the costs of expensive legal cases by experimenting with novel means of dispute processing, management and funding, with any subsequent enhancement of citizen access (or political or professional legitimacy) a positive but

31 Roberto Mangabeira Unger Law in Modern Society: Toward a Criticism of Social Theory (Free Press, New York, 1976) 192.

32 Erhard Blankenburg "Comparing Legal Aid Schemes in Europe" (1992) 11 Civil Justice Quarterly 106.

33 Gross expenditure on legal aid in New Zealand appears to be declining from $\$ 86,441,000$ in $1998 / 99$ to $\$ 79,251,000$ in 2000/2001. See Legal Services Agency 2000-2001 Annual Report and Business Plan 20012004: Looking Forward (Legal Services Agency, Wellington, 2002) (LSA) 67. Legal aid expenditure has in recent years been about double the rate of annual inflation although there are signs that government policy is now beginning to exercise some control over costs. It is estimated that at present some $30 \%$ of the total turnover of the Bar and $15 \%$ of the turnover of solicitors comes from legal aid. See further Roger Smith Justice: Redressing the Balance (Legal Action Group, London, 1997). 
secondary side-effect. If it is correct that the primary objective of governmental access reforms is simply to reduce the financial burden on the State does it follow that ultimately they are doomed to failure or are irrelevant to the quest for deeper (or even more pragmatic) conceptions of justice?

At this point it may be instructive to remind ourselves of the Florence Access to Justice Project and the underlying philosophy it advocated of "making rights effective". ${ }^{34}$ The liberal political theory informing this project, which I believe remains valid even today, was to shift the emphasis away from formal rights towards substantive justice. Cappelletti's analysis of contemporary judicial review refers to an evolutionary continuum linking the French Revolution, the Universal Declaration of Human Rights, and the internationalism of the human rights movement, particularly during the post-war period, which finally embraces the development of regional human rights. But the main conclusion arrived at is not so much that we need more rights - or more statements of rights (important as these may be for constitutional lawyers or political symbolism) - rather the ongoing challenge is to find new ways and means of making the rights citizens already possess both "effective" and "enforceable". It follows that through rigorous procedural scholarship on the nature, scope and role of civil justice systems in delivering the abstract rights often enshrined in legal rhetoric we can expose the deficiency and hypocrisy surrounding constitutional discourse. This essentially "English" perspective places greater emphasis on the pragmatic means for enhancing and delivering the accessibility of law and the legal system rather than giving legal expression to a constitutional "right of action".

The analytical framework developed by the Florence Access to Justice Project was structured around the metaphor of three waves: the first was legal aid (or judicare); the second, public interest law - the articulation of the representation of collective rights through class actions and public interest litigation; and the third, what has now come to be called the "access to justice approach" including informal justice, diversion of cases away from the formal legal system and the simplification of law. ${ }^{35}$ These themes associated with the third wave are very topical in England at the present time following a major investigation of the whole civil justice system led by Lord

34 Mauro Cappelletti and Bryan Garth (eds) Access to Justice (Milan, Giuffrè, 1978); (Alphen aan den Rijn, Sijthoff and Noordhoff, 1978-1979). Mauro Cappelletti and James Gordley "Legal Aid: Modern Themes and Variations" (1972) 24 Stan L Rev 347.

35 Cappelletti and Gordley, above. Lewis points out that the metaphor of "waves" or "tendencies" is not entirely satisfactory, "not just because comparative lawyers assume that changes fulfil similar needs but also because they assume that we have a satisfactory account merely by showing the existence of apparently similar countries, whereas this only begins the inquiry into the circumstances underlying those similarities" in Richard Abel and Philip Lewis (eds) Lawyers in Society: Comparative Theories (University of California Press, Berkeley, 1989) 71. 
Woolf. This review has questioned basic tenets of English civil procedure with a view to improving and cutting the growing costs of the civil justice system. ${ }^{36}$

One question that might usefully be asked of these "third wave" reforms is whether in essence they promote "access to justice" or "access to peace". By that I mean that dispute resolution is not necessarily to be equated with access to justice. The danger I wish to draw attention to is the fact that citizens may be offered peaceful solutions, possibly even solutions with which they are extremely happy and content, but such solutions could result in something less than they would receive were they to enforce their formal rights through the official legal system. In such circumstances there is a very real danger with this fashionable and ubiquitous trend toward legal informalism, namely that we end up negating many of the values, importance and historical significance of legal formalism. ${ }^{37}$ The metaphor of "waves" is perhaps simplistic, but it does serve to identify certain crucial phases regarding the intellectual and policy developments produced by this global access to justice movement.

\section{JOURNEY TO AN UNKNOWN DESTINATION?}

By way of conclusion, drawing upon another of Roberto Unger's insights that: ${ }^{38}$

... we can account for a basic, common experience in modern society ... the sense of being surrounded by injustice without knowing where justice lies. This condition is the political side of that more general sentiment of arbitrariness and even absurdity which gradually enters into the consciousness of every group,

I wish to identify a fourth, perhaps final, wave of the access to justice movement, namely lawyers' (including judicial and all others involved in the legal services industry) access to justice. Within the "consciousness" of the legal profession there exists a curious, almost invisible, paradox: how can lawyers who are directly involved in the administration of justice themselves comprehend "access to justice"? The daily experiences of lawyers and their very proximity to "justice" perhaps blinds them to more profound conceptions of justice (internal or social) and, consequently, allows the profession to ignore the relationship between civil and civic justice. Our "fourth wave" seeks to

36 Lord Woolf Access to Justice: Final Report to the Lord Chancellor on the Civil Justice System in England and Wales (1996) available at <http://www.law.warwick.ac.uk/woolf/>.

37 Richard L Abel (ed) The Politics of Informal Justice (Academic Press, New York, 1982); Richard Abel "Conservative Conflict and the Reproduction of Capitalism: The Role of Informal Justice" (1981) 9 International Journal of Society and Law 245. See also Michael Palmer and Simon Roberts Dispute Processes: ADR and the Primary Forms of Decision Making (Butterworths, London, 1998).

38 Robert Mangabeira Unger Law in Modern Society: Toward a Criticism of Social Theory (Free Press, New York, 1976) 192. 
expose the ethical and political dimensions to the administration of justice and, at the same time, establish new links between professional responsibility and legal education. ${ }^{39}$

The problem today is not one of simply measuring citizens' access to justice, for example through mapping gaps in legal service provision, but rather of opening up new perspectives on defining justice itself. I therefore propose a major shift from methodological to epistemological questions, or, put another way, to re-focus our attention away from access to looking afresh at justice. To what kind of "justice" should citizens aspire? Instead of concentrating on citizens' access from the demand side, I would like to suggest we move on to consider more carefully citizens' access to justice, but from the supply side and at two distinct levels: first, citizens' access to legal education and entry to the legal profession; second, once qualified, lawyers' access to justice. Having surmounted the barriers to entry to the courts and the legal profession, how can citizens ensure that either judges or lawyers will be equipped to deliver "justice"?

The first issue I wish to raise then is access to legal education: who can qualify as a lawyer or a judge? Who has access to law school? Since law schools invariably are the gatekeepers to the legal profession we need to understand who has access to them and on what basis. Is entry primarily governed according to nepotistic or meritocratic principles? Should government, the professional bodies and individual lawyers do more to promote positively access to the legal profession on behalf of women, disadvantaged minorities and other groups who are socially, or historically, excluded ${ }^{40}$ Thus, access to the legal profession should be seen as an important dimension, even precondition, to the question of citizens' access to justice.

The second and more difficult question is how to guarantee, once they are inside the profession, that both lawyers and judges have access to justice. This raises in turn ethical issues concerning the wider responsibilities of law schools and the professional bodies in controlling not only entry but also determining standards. These issues are present in most modern legal systems all of which struggle with reconciling tensions between maintaining the quality of, and access to, justice. ${ }^{41}$

Before either of these two questions can be properly answered we need to understand better the role and responsibilities of law schools in the formation of lawyers' professional character. It

39 For discussions of lawyers' detachment from core professional values and the role of education in counteracting "value devaluation" see Kim Economides "What are Fundamental Legal Values?" in Kim Economides (ed) Fundamental Values: A Volume of Essays to Commemorate the 75th Anniversary of the Founding of the Law School in Exeter 1923-1998 (Hart, Oxford, 2000) 12-13; Kim Economides (ed) Ethical Challenges to Legal Education \& Conduct (Hart, Oxford, 1998).

40 Rajeev Dhavan, Neil Kibble and William Twining (eds) Access to Legal Education and the Legal Profession (Butterworths, London, 1989).

41 With a view to exploring further such ethical dilemmas, I am currently involved in comparative studies of the teaching of legal ethics; see Economides, above, and professional codes of conduct. See also the journal entitled "Legal Ethics" (see: <http://members.aol.com/legalethic/open.htm>). 
appears that in many jurisdictions there is a widespread cynicism about law, lawyers and justice which may even be encouraged by what goes on in law schools. ${ }^{42}$ In many societies the law is perceived to be (and often is) out of reach; justice is some distant Utopian, and therefore unattainable, ideal; and lawyers the object of cynical humour, rather than deserving of the public's trust, confidence and respect. ${ }^{43}$ Legal ethics is often seen as an oxymoron and the relationship between lawyers and justice is at best highly problematic. Are not lawyers almost everywhere characterised as being primarily motivated by the pursuit of profit rather than their commitment to justice and ethical practice? If so, is this a consequence of the fact that legal education typically concentrates on doctrinal rather than contextual analysis and subscribes to a strong positivist tradition which rigidly separates law from morals?

Answers to such questions may become clearer if we begin to examine cross-culturally both the "macro" dimension to the distribution of law as a resource as well as the "micro" dimension of professional responsibility. A useful starting point might be to consider the statements concerning lawyers' responsibilities enshrined in their constitutions, the professional code of conduct. ${ }^{44}$ These must be examined in terms of how far they promote and sustain equal opportunities, humane professionalism and human rights. Perhaps they are silent about such values preferring instead to focus on policing conduct as opposed to eradicating injustice. Professional values, as well as technical competence, need to be communicated and handed down to the next generation of lawyers. Although many law schools provide instruction in the field of human rights law this area will often be given no higher status than many other areas of the curriculum. I would like to argue that human rights should be accorded special status in the curriculum because of its central relevance to both citizenship and professionalism. Some might go further and argue that the modern lawyer needs some equivalent to the medics' Hippocratic oath. ${ }^{45}$ What we clearly need at the present

42 Kim Economides "Cynical Legal Studies" in Jeremy Cooper and Louise Trubek (eds) Educating for Justice: Social Values and Legal Education (Dartmouth, Aldershot, 1997).

43 Although in New Zealand a "lawyer" may refer to "a horrid thorny vine or bushy tangle from whose clutches a victim escapes only with difficulty and at great personal cost": New Zealand Slang Dictionary (Reed, Auckland, 1992). See also: T Overton, "Lawyers, Light Bulbs, and Dead Snakes: the Lawyer Joke as Societal Text" (1995) 42 UCLA L Rev 1069. Mark Galanter, "The Faces of Mistrust: the Image of Lawyers in Public Opinion, Jokes, and Political Discourse" (1998) 66 Univ Cincinnati L Rev 805.

44 See New Zealand Law Society Rules of Professional Conduct for Barristers and Solicitors (6 ed, NZLS, Wellington, 2000); updates reported at: http: <www.nz-lawsoc.org.nz>; Duncan Webb Ethics, Professional Responsibility and the Lawyer (Butterworths, Wellington, 2000). See also the accounts of the professional codes in Canada and Australia in Kim Economides (ed) Ethical Challenges to Legal Education \& Conduct (Hart, Oxford, 1998) Chaps 6-7.

45 In many countries, lawyers swear a professional oath, either when they graduate from law school or when they enter the Bar. But, viewed from the perspective of "cynical legal studies" (Economides, above) there remains always a risk that the lawyers' equivalent of the Hippocratic oath is reduced to nothing more than a hypocritical oath. See also the arguments of Potter LJ in favour of a critical re-appraisal of the codes of 
time is a wide-ranging discussion of the fundamental values that should govern lawyers wherever they choose to practise. ${ }^{46}$

Responsibility for promoting and widening access to legal education, law and justice might become more of a collaborative project between law schools, government and the professional bodies. What are the responsibilities of law schools in equipping future lawyers to service the legal needs of the public? Not simply at the level of inculcating skill, in terms of teaching legal method and the craft of law, but rather communicating something of the value and potential of law in terms of its power to transform social relations and ameliorate the human condition. Professional and governmental bodies which control entry to, and regulate the conduct of, legal professions also have a significant role to play in directing legal services to fill gaps left uncovered by the market. New Zealand is to be congratulated on taking a lead in bringing ethical concerns to the fore of the law curriculum. You are particularly fortunate to have a Law Faculty here at Victoria University ideally placed, by virtue of its traditions and location, to continue mapping and exploring the path or paths to justice. As so often in human endeavour, one suspects the journey along the way may well prove more significant than reaching that final, perhaps unattainable, destination.

conduct: Hon Mark Potter "The Ethical Challenges Facing Lawyers in the Twenty-First Century" (2001) 4 Legal Ethics 23, 39.

46 See, for example, Mike Martin Meaningful Work: Rethinking Professional Ethics (Oxford University Press, Oxford, 2000). 
